\title{
DRYING SOME MEDICINAL AND AROMATIC PLANTS BY MICROWAVE
}

\author{
Taghreed H. Ahmed*
}

\begin{abstract}
In this investigation, four different medicinal and aromatic plants chamomile, mint, sage and basil were dried by microwave under three different levels of power density (6.7, 10 and 20) W.g $\mathrm{g}^{-1}$ in order to study drying characteristics, energy consumption and drying efficiency for microwave drying. The experimented plants were dried to the final moisture content during (12,10 and 9) min for chamomile, while mint leaves took 9, 6 and 4 min, it took 9, 7 and 5 min for drying sage leaves and basil leaves took 14, 8 and 5 min for power density of (6.7, 10 and 20)W. $\mathrm{g}^{-1}$ respectively. The minimum specific energy consumption and

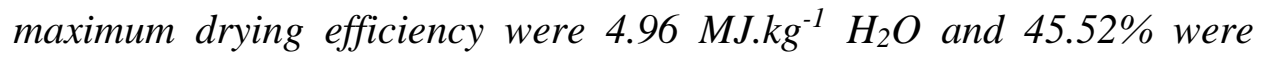
computed for drying sage samples using $6.7 \mathrm{~W} . \mathrm{g}^{-1}$ power density. Among the mathematical models investigated there are six thin layer drying models were fitted to the experimental moisture ratio data, the page and page I models satisfactorily described the drying behavior of basil leaves at $6.7 \mathrm{~W} . \mathrm{g}^{-1}$ and mint leaves at 10,20 W. $\mathrm{g}^{-1}$ with highest $r^{2}$ values but for the other treatments Newton model and Henderson and Pabis model were the best. The moisture diffusivity increased with microwave power density. The lowest values of effective moisture diffusivity were $\left(5.03739 \times 10^{-8}, \quad 6.01782 \times 10^{-10}, \quad 1.72664 \times 10^{-9}, \quad 5.769 \times 10^{-10} \mathrm{~m}^{2} . \mathrm{s}^{-1}\right)$ of chamomile, mint, sage, basil respectively at the lowest power density.
\end{abstract}

\section{INTRODUCTION}

$\mathrm{D}$ ehydration is still one of the most challenging operations in food processing, as the food preservation through the partial water remove dates back several centuries in order to stop the growth of bacteria, yeasts and molds that normally spoil food, So it plays an important role in preserving perishable products including medicinal and aromatic plants and it can be accomplished by several methods such as

\section{${ }^{*}$ Lecturer of Agric. Eng., Fac. of Agric., Zagazig Univ.}


sun drying, hot air drying, freeze drying and microwave drying which is recently has been applied to numbers of agricultural products in general. The drying process should be undertaken in closed equipment to improve the quality of the final product (Ertekin and Yaldiz, 2004).

As a medicinal culture, wild chamomile is acknowledged by the pharmacopoeias of practically all countries of the world. Moreover the dried flower heads of wild chamomile are widely used in perfumery and cosmetics. Sage has a great industrial significance; many Mediterranean countries where it grows have substantial gains from the production and export of sage (Amr and Dordevic, 2000), it has a very old reputation to calm nervousness and cure digestive troubles (Kouhila et al., 2001). The microwave drying prevents the food from enzymatic decomposition and reduces the drying time compared with sun drying and hot air drying, furthermore microwave drying is an alternative method because of its uniform energy and high thermal conductivity to the inner sides of the material, space utilization, sanitation, energy saving and fast startup and shutdown conditions. (Zhang et al., 2006).

(Demirhan and Özebk, 2010) investigated the effect of microwavedrying technique on moisture content, moisture ratio, drying time, drying rate and effective moisture diffusivity of basil leaves they found increasing the microwave output power (180-900 W) and the sample amounts (25-100 g), the drying time decreased from 28 to $6.5 \mathrm{~min}$ and increased from 16 to $44 \mathrm{~min}$, respectively.

Microwave energy overcomes the problem of very high heat transfer and conduction resistances, leading to higher drying rates. These high drying rates correspond also to lower shrinkage and to the retention of water insoluble. (Erle, 2000).

When the microwave energy is turned off and the food is removed from the oven, there is no residual radiation remaining in the food. In this regard, the microwave is much like an electric light that stops glowing when it is turned off (Gallawa and Microtech Prod., 1989-2005).

(Minaei et al. 2012) reported that microwave drying is more uniform, more rapid and more highly energy efficient when it compared to conventional hot air drying and infrared drying. 
Many researches on the mathematical modeling and experimental studies have been conducted on the thin layer drying processes of various vegetables, fruits and agriculture products such as green chili (Hossain and Bala, 2002), pistachio (Midilli and Kucuk, 2003), potato (Akpinar et al., 2003a), pumpkin (Akpinar et al., 2003b), eggplant (Ertekin and Yaldiz, 2004), carrot (Doymaz, 2004), rosehip (Erenturk et al., 2004), fig (Doymaz, 2005), kiwi (Simal et al., 2005) and bay leaves (Günhan et al., 2005).

The effective moisture diffusivity of a food material characterizes its intrinsic mass transfer property of moisture. During drying, it can be assumed that diffusivity, explained with Fick's diffusion equation, is the only physical mechanism to transfer the water to surface (Wang et al. 2007).

So, the main objectives of this study were to:

- Study the influence of microwave power density on the drying characteristics, specific energy consumption and drying efficiency of some medicinal and aromatic plants.

- Compare the measured findings obtained during the drying of the experimented plants with the predicted values obtained with six mathematical models and predict the drying behavior dependable on a mathematical model.

- Estimate the effective moisture diffusivity.

\section{MATERIALS AND METHODS}

Experiments were carried out during 2017 at Faculty of Agriculture, Zagazig University, Egypt in order to select the proper conditions for drying some medicinal and aromatic plants in a microwave.

- Drying equipment:

The drying experiments were conducted using a domestic microwave oven, model KOC-185V, Daewoo type, $50 \mathrm{MHz}$, power output $1000 \mathrm{~W}$ and made in Egypt.

\section{- Experimental procedure:}

The performance of the drying process was experimentally measured under the following parameters:

- Fresh leaves of four different types of medicinal and aromatic plants: chamomile (Matricaria Chamomilla L.), mint (Mentha 
piperita L.), sage (Salvia officinalis L.) and basil (Ocimum basilicum L.).

- Three different levels of power density $\left(6.7,10\right.$ and $\left.20 \mathrm{~W} \cdot \mathrm{g}^{-1}\right)$.

\section{- Measurements and Determinations:}

Evaluate the performance of drying process was based on the following indicators:

\section{- Moisture content:}

The average moisture content of fresh samples was determined by drying samples in a vacuum oven at $105^{\circ} \mathrm{C}$ until constant weight was reached (AOAC, 2000). Moisture contents of fresh samples were 79.30, 80.00, 85.00 and $79.00 \%$ w.b. for chamomile, mint, sage and basil, respectively. The moisture losses of samples were recorded at every $1 \mathrm{~min}$ intervals during the drying process.

Drying process was carried out until the equilibrium moisture content reaches to a level about 10\% (wb) according to (Gölükcü, 2015).

\section{- Drying rate}

Drying rate $\left(\mathrm{g} \cdot \mathrm{min}^{-1}\right)$ was calculated as following:

$$
\text { Drying rate }=\frac{\left(M_{t+d t}-M_{t}\right)}{(d t)}
$$

Where: $\mathrm{M}_{\mathrm{t}}$ : Moisture content (g water/g dry matter) at time (t); $\mathrm{M}_{\mathrm{t}+\mathrm{dt}}$ : Moisture content ( $\mathrm{g}$ water/g dry matter) at time $(\mathrm{t}+\mathrm{dt})$.

\section{- Specific energy and drying efficiency}

Energy consumption in drying $\left(\mathrm{E}_{\mathrm{t}}, \mathrm{W}\right.$. min) was calculated as following:

Where: P: Power requirements, $\mathrm{W}$

$$
\mathbf{E}_{\mathbf{t}}=\mathbf{p} \times \mathbf{t}
$$

$\mathrm{t}$ : Drying time, min.

The specific energy $\left(\mathrm{E}_{\mathrm{s}}, \mathrm{MJ} / \mathrm{kg}_{\text {water }}\right)$ was calculated as the energy needed to evaporate a unit mass of water (Soysal et al., 2006).

$$
E_{s}=\frac{60 \times E_{t}}{1000 \times m_{w}}
$$

The drying efficiency $(\eta, \%)$ was calculated as the ratio of the heat energy utilized for evaporating water from the sample to the heat supplied (Soysal, 2004). 


$$
\eta=\frac{m_{w} \times \lambda_{w}}{E_{t} \times 60} \times 100
$$

Where: $\mathrm{m}_{\mathrm{w}}$ : Mass of evaporated water, $\mathrm{g} ; \lambda_{\mathrm{w}}$ : Latent heat of vaporization of water, $\mathrm{kJ} / \mathrm{kg}$.

The latent heat of vaporization of water at the evaporating temperature of

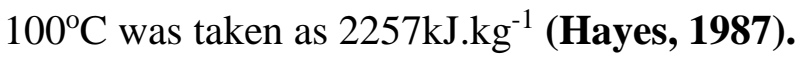

\section{- Moisture ratio and mathematical modeling:}

The moisture ratio (MR) was calculated using the following equation:

$$
M R=\frac{M_{t}-M_{f}}{M_{i}-M_{f}}
$$

Where:

$\mathrm{M}_{\mathrm{t}}$ : Moisture content at $\mathrm{t}, \mathrm{db} ., \mathrm{M}_{\mathrm{f}}$ : the final moisture content, $\mathrm{db}$. and $\mathrm{M}_{\mathrm{i}}$ : the initial moisture content, $\mathrm{db}$.

Six semi-empirical models listed in Table (1) were used to fit the experimental moisture data because they explain the characteristic of the drying method safely and they used widely in drying plants.

The terms used to evaluate the quality of the fit of the examined models to the several statistical parameters such as; coefficient of determination $\left(\mathrm{R}^{2}\right)$, reduced chi-square (X2), mean bias error (MBE) and root mean square error (RMSE), these parameters calculated as follows:

$$
\begin{gathered}
x^{2}=\frac{\sum_{i=1}^{n}\left(M R_{\exp , i}-M R_{p r e, i}\right)^{2}}{N-n} \\
M B E=\frac{1}{N} \sum_{i=1}^{N}\left(M R_{p r e, i}-M R_{\exp , i}\right) \\
R M S E=\left[\frac{1}{N} \sum_{i=1}^{n}\left(M R_{p r e, i}-M R_{\text {exp }, i}\right)^{2}\right]^{\frac{1}{2}}
\end{gathered}
$$

Where: $\mathrm{MR}_{\exp , \mathrm{i}}$ : The stands for the experimental moisture ratio found in any measurement; $\mathrm{MR}_{\mathrm{pre}, \mathrm{i}}$ : Predicted moisture ratio for this measurement; $\mathrm{N}$ : Number of observations; $\mathrm{n}$ : Number constants.

\section{Determination of effective moisture diffusivity:}

It has been generally accepted that the drying phenomenon of biological materials is controlled by the mechanism of moisture diffusion during the falling rate period. The experimental drying data for the determination of diffusivity coefficients were interpreted by using Fick's second diffusion 
model, as shown in the following equation, has been frequently used to describe the internal moisture transfer during drying process.

$$
\frac{\partial M}{\partial t}=D_{e f f} \nabla^{2} M
$$

The solution of Fick's equation for slab geometry is solved by Crank (1975) and supposed uniform initial moisture distribution, negligible external resistance, constant diffusivity and negligible shrinkage:

$$
M R=\frac{8}{\pi^{2}} \sum_{n=0}^{\infty} \frac{1}{(2 n+1)^{2}} \exp \left(-\frac{(2 n+1)^{2} \pi^{2} D_{e f f} t}{4 L^{2}}\right)
$$

Where: $D_{\text {eff }}$ is the effective moisture diffusivity, $\mathrm{m}^{2} \cdot \mathrm{s}^{-1}, \mathrm{t}$ is the time, $\mathrm{s}$., $\mathrm{L}$ is the half thickness of samples, $\mathrm{m}$. and $\mathrm{n}$ is a positive integer.

For long drying times, a limiting of this equation is obtained and expressed in a logarithmic form (Madamba 2003):

$$
\ln M R=\ln \frac{8}{\pi^{2}}-\frac{\pi^{2} D_{e f f} t}{4 L^{2}}
$$

The effective diffusivity is typically calculated by plotting experimental

\begin{tabular}{|c|c|c|c|}
\hline $\begin{array}{l}\text { Model } \\
\text { No }\end{array}$ & $\begin{array}{l}\text { Model } \\
\text { Name }\end{array}$ & Model & References \\
\hline $\mathbf{1}$ & $\overline{\text { Newton }}$ & $\mathrm{MR}=\exp (-\mathrm{kt})$ & $\begin{array}{l}\text { (O'Callaghan et al., 1971) and } \\
\text { (Liu and Bakker-Arkema, 1997). }\end{array}$ \\
\hline 2 & Page & $\mathrm{MR}=\exp \left(-\mathrm{kt}^{\mathrm{n}}\right)$ & $\begin{array}{l}\text { (Agrawal and Singh, 1977) and } \\
\text { (Zhang and Litchfield, 1991). }\end{array}$ \\
\hline 3 & $\begin{array}{l}\text { Modified } \\
\text { Page (I) }\end{array}$ & $\mathrm{MR}=\exp \left[-(\mathrm{kt})^{\mathrm{n}}\right]$ & $\begin{array}{l}\text { (Agrawal and Singh, 1977) and } \\
\text { (Zhang and Litchfield, 1991). }\end{array}$ \\
\hline 4 & $\begin{array}{l}\text { Modified } \\
\text { Page (II) }\end{array}$ & $\begin{array}{l}\mathrm{MR}=\exp \\
{[(-\mathrm{k}(\mathrm{t} / \mathrm{L} 2) \mathrm{n})]}\end{array}$ & Diamante and Munro (1991) \\
\hline 5 & $\begin{array}{c}\text { Henderson } \\
\text { and Pabis }\end{array}$ & $\mathrm{MR}=\mathrm{a} \exp (-\mathrm{kt})$ & $\begin{array}{l}\text { (Westerman et al., 1973) and } \\
\text { (Chhninman, 1984). }\end{array}$ \\
\hline 6 & Linear & $\mathrm{MR}=1+\mathrm{bt}$ & - \\
\hline
\end{tabular}
drying data in terms of $\ln (\mathrm{MR})$ versus time.

Table (1): Mathematical models for the drying curves: 


\section{RESULTS AND DISCUSSION}

The discussion will cover the obtained results under the following heads:

\section{1-Moisture content versus drying time according to different microwave power densities:}

Curves of moisture content versus drying time according to different microwave power densities for experimented samples are presented in Figure1. It is apparent that moisture content decreases continuously with increasing drying time. The entire drying process for experimented plants occurs in the range of the falling-rate period. This shows that diffusion in dominant physical mechanism governing moisture movement in the samples, similar results were obtained by other authors working on drying of various agricultural products drying (Akpinar et al. 2003).

The experimented plants chamomile, mint, sage and basil were dried as a single layer at $6.7,10$ and $20 \mathrm{~W} . \mathrm{g}^{-1}$ drying microwave power densities.

It was observed that the decrease in drying time and decrease of moisture content were obtained with an increase in the drying microwave power density for experimented plants' leaves.

It can be seen that concerned to the power densities of $6.7,10$ and $20 \mathrm{~W} . \mathrm{g}^{-1}$ drying chamomile samples from the initial moisture content to final moisture content of $10.17,10.4$ and $11.5 \%$ wb only took 12,10 and 9 min. With regard to dry mint samples it took 9,6 and 4 min to achieve final moisture content of $12.67,15.20$ and $13.00 \%$ wb. For sage samples it took 9, 7 and 5 min to attain a result of final moisture content of 12.4, 10.5 and $9.00 \%$ wb. Basil samples achieved final moisture content of $11.60,12.60$ and $9.60 \% \mathrm{wb}$ at 14,8 and 5 min respectively.

The decrease in drying time with an increase in the drying microwave power density has been reported for many foodstuffs, such as mint leaves (Ozbek and Dadali, 2007), onions (Arslan and Ozcan, 2010) and potato slices (Darvishi 2012).

\section{The changes in drying rate as a function of drying time:}

Figure (2) showed the relation between drying rate and drying time attributed to experimental power density. It was observed that drying rate decreased with increasing in drying time. There was not any constant-rate drying period and all the drying operations are seen to occur in the falling rate period. The drying rates were higher at the beginning of the drying operation. 

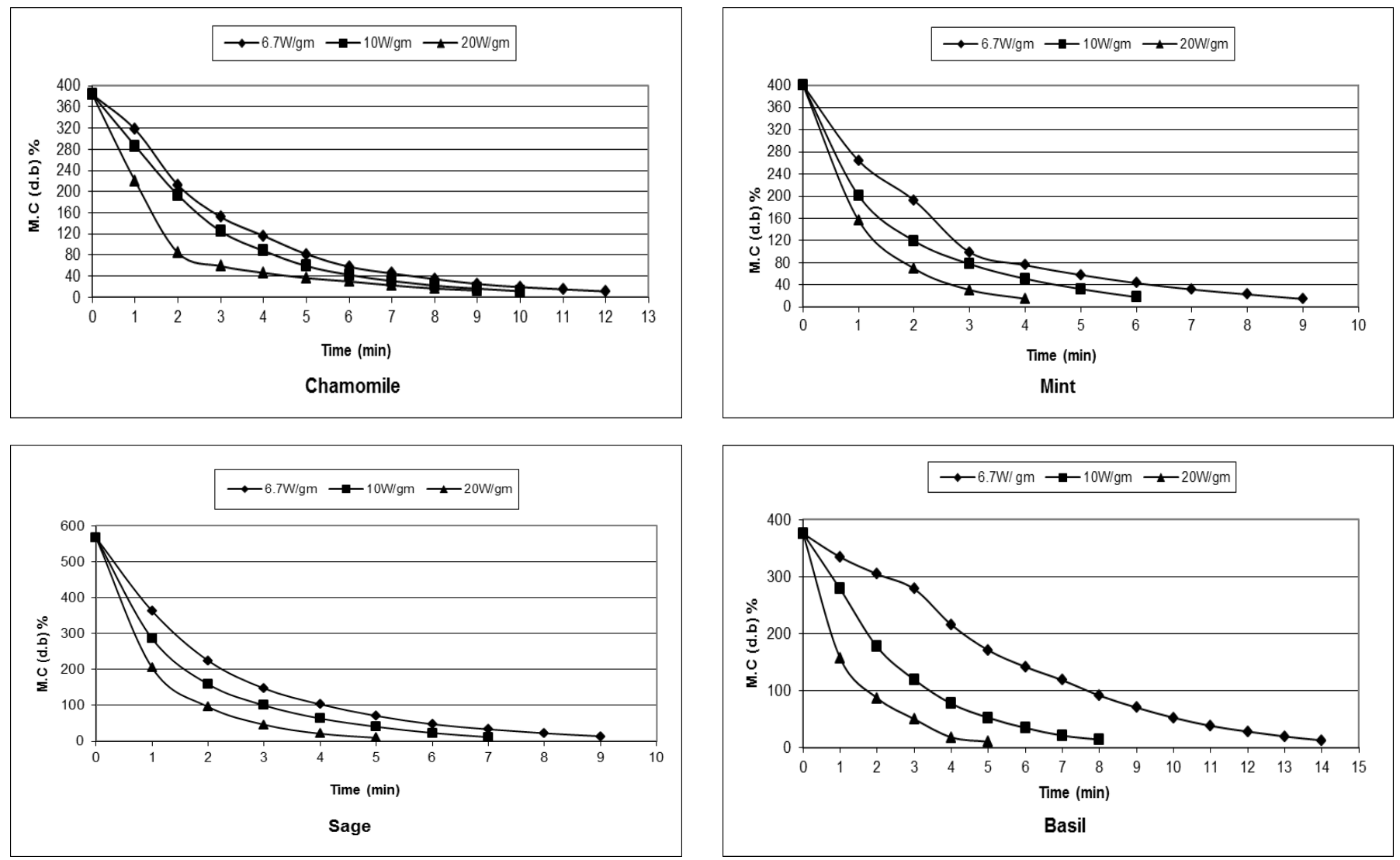

Figure (1) Moisture content versus drying time according to different microwave power densities. 

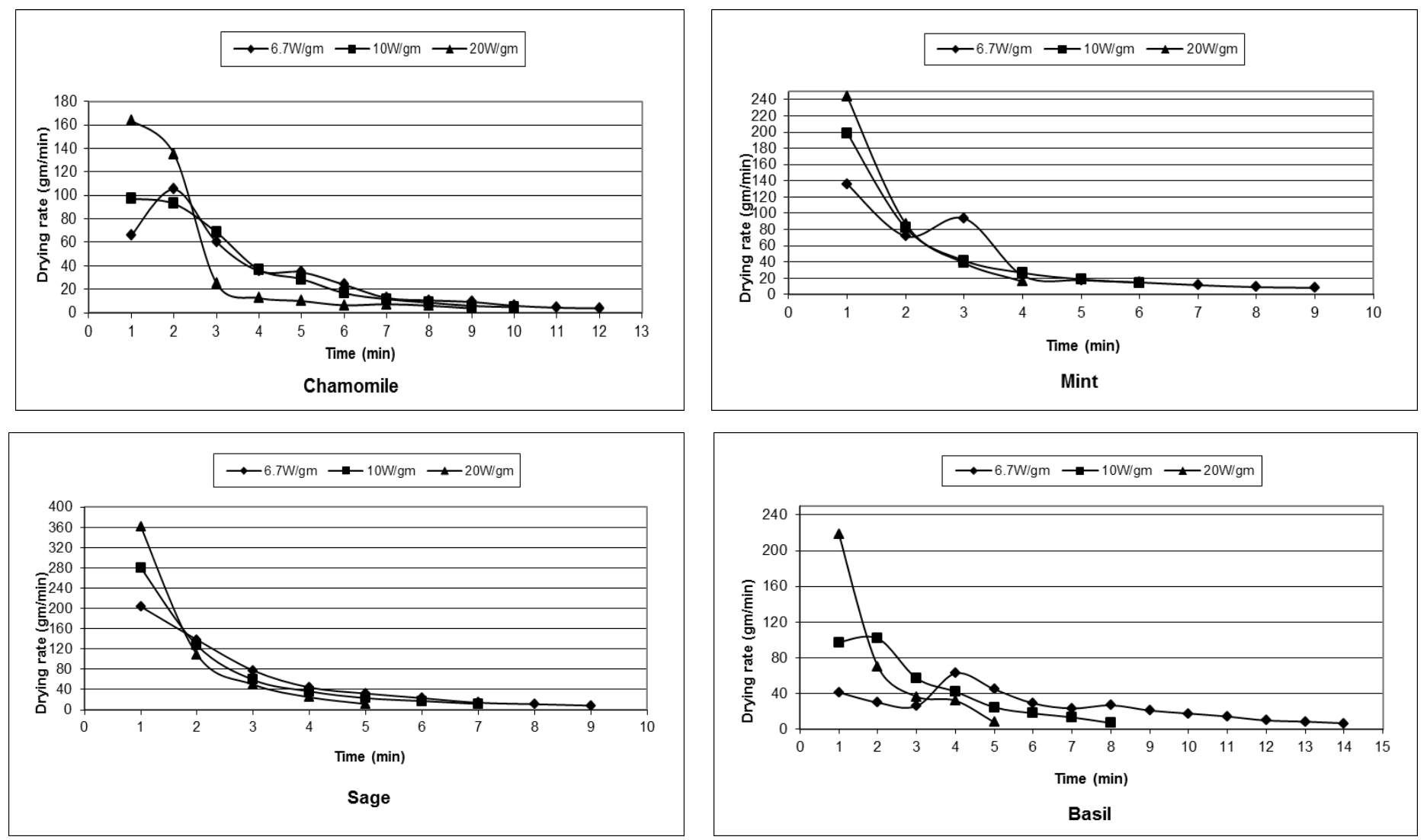

Figure (2) Effect of drying time on the behavior of drying rate according to different microwave power densities 
The drying rate curves for chamomile, mint, sage and basil leaves dried at selected levels of microwave power density are shown in Figure (2). It was observed that at the beginning of drying process, the effect of power density on drying rate was worthy effect on drying rate but increasing time made the effect of power density not noticeable.

\section{Variations of drying rate as a function of moisture content attributed to power density:}

It was observed drying rate decreased with the decrease in moisture content and increased with increasing power density, and thence decreasing drying time. The results obtained have shown that during higher microwave power heating mass transfer within the sample was more rapidly because more heat was produced within the sample generating a large vapor pressure inequality between the center and the surface of the product due to the fact of volumetric heating of microwave. At the beginning of the drying operation it was observed that the drying rates were higher, while the product moisture content was higher.

\section{Estimations of Specific Energy Consumption and Drying Efficiency:}

The variations of specific energy consumption and drying efficiency values for experimented plants were shown in table (1) and figure (4) respectively. Results showed that specific energy consumption increased while drying efficiency decreased continuously as power density were increased except for basil leaves the power density of $6.7 \mathrm{~W} . \mathrm{g}^{-1}$ attained specific energy consumption higher than of $10 \mathrm{~W} \cdot \mathrm{g}^{-1}$ due to the leaves of basil have consumed more time to dry more than expected at the same power density. It is observed that the minimum specific energy consumption and maximum drying efficiency were $4.96 \mathrm{MJ}^{\mathrm{kg}} \mathrm{kg}^{-1} \mathrm{H} 2 \mathrm{O}$ and $45.52 \%$ were computed for drying sage samples using $6.7 \mathrm{~W} . \mathrm{g}^{-1}$ power density, while the maximum specific energy consumption was 15.93 MJ. $\mathrm{kg}^{-1} \mathrm{H} 2 \mathrm{O}$ and minimum drying efficiency was $14.17 \%$ were computed for drying chamomile samples using power density of $20 \mathrm{~W} \cdot \mathrm{g}^{-1}$. 

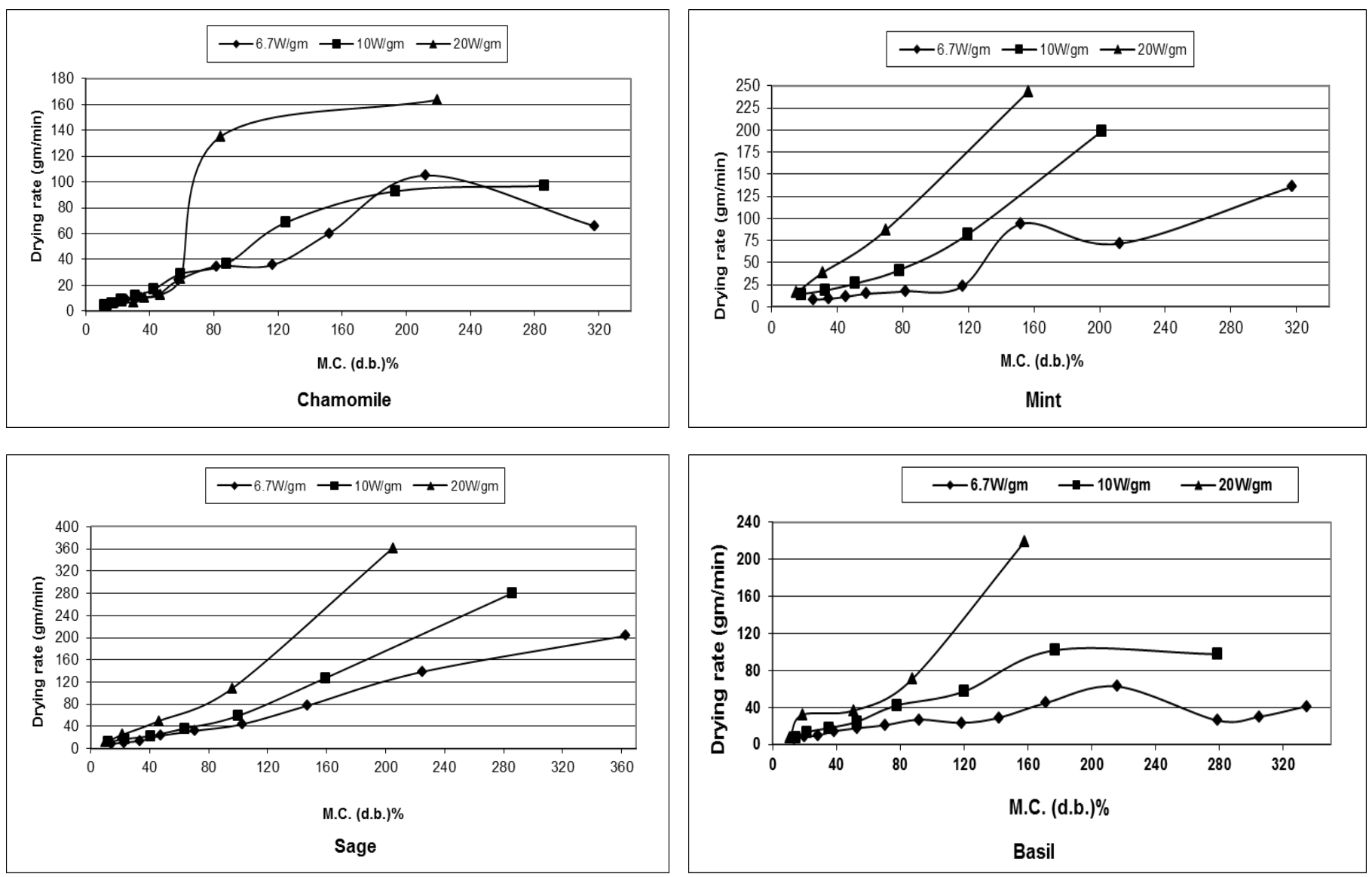

Figure (3) Variations of drying rate as a function of moisture content attributed to power density. 
Table (2) Influence of microwave power density on specific energy consumption:

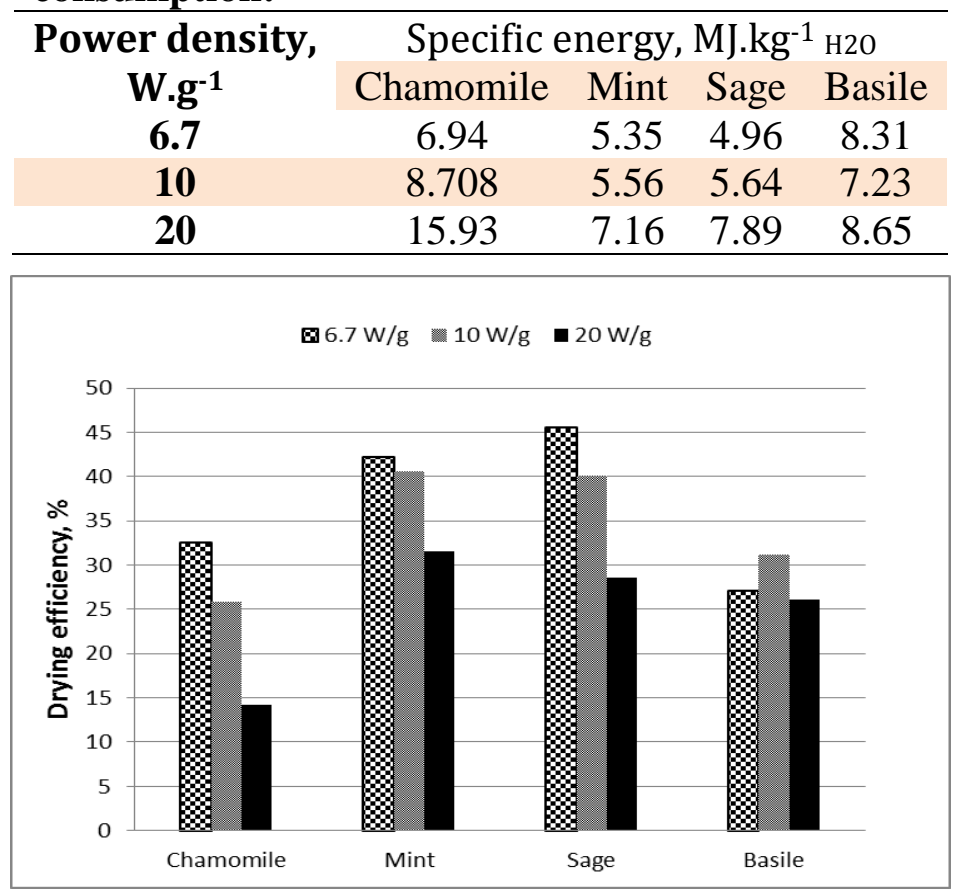

Figure (4) Influence of microwave power density on drying efficiency.

\section{Mathematical models for fitting drying curves of the experimented plants:}

The statistical computations results of the microwave drying data which undertaken to assess the fitting ability of 6 drying models expressing the changes in the moisture ratio versus drying time are presented in Tables $(3,4,5,6)$ as the values of the coefficients and statistical parameters found for the models. The models were evaluated based on $\mathrm{R}^{2}, \mathrm{X} 2$, MBE and RMSE. It was observed that model of Newton and model of Henderson and Pabis were the best descriptive models for chamomile at all levels of power density. For mint at power density of $6.7 \mathrm{~W} \cdot \mathrm{g}^{-1}$ the most descriptive models were Newton and Henderson and Pabis, while at $10 \mathrm{~W} . \mathrm{g}^{-1}$ and $20 \mathrm{~W} . \mathrm{g}^{-1}$ the models Page, Modified Page (I) and Modified Page (II) were the best. Page model was the best one for sage. The most suitable models for basil were Page, Modified Page (I) with power density of $6.7 \mathrm{~W} . \mathrm{g}^{-1}$, but at $10 \mathrm{~W} \cdot \mathrm{g}^{-1}$ and $20 \mathrm{~W} \cdot \mathrm{g}^{-1}$ the best models were Newton and Henderson and Pabis. 
Table (3): Statistical parameters and the values of the coefficients specific to each model according to various microwave power densities for chamomile:

\begin{tabular}{|c|c|c|c|c|c|c|c|c|c|}
\hline \multirow{2}{*}{ Model } & \multirow{2}{*}{ power density } & \multicolumn{4}{|c|}{ Constants } & \multirow{2}{*}{$\mathbf{R}^{2}$} & \multirow{2}{*}{ MBE } & \multirow{2}{*}{$X^{2}$} & \multirow{2}{*}{ RMSE } \\
\hline & & $\mathbf{k}$ & $\mathbf{n}$ & $\mathbf{a}$ & $\mathbf{b}$ & & & & \\
\hline \multirow{3}{*}{ Newton } & 6.7 & 0.2985 & & & & 0.997 & -0.00376 & 0.00072 & 0.02605 \\
\hline & 10 & 0.3538 & & & & 0.997 & 0.00036 & 0.00034 & 0.01755 \\
\hline & 20 & 0.0347 & & & & 0.935 & 0.69086 & 0.54975 & 0.69904 \\
\hline \multirow{3}{*}{ Page } & 6.7 & 3.6255 & 0.88 & & & 0.985 & -0.23433 & 0.12966 & 0.32871 \\
\hline & 10 & 2.9212 & 0.936 & & & 0.994 & -0.22258 & 0.11728 & 0.30630 \\
\hline & 20 & 1.6820 & 1.269 & & & 0.933 & -0.13038 & 0.03577 & 0.16681 \\
\hline \multirow{3}{*}{ Modified Page (I) } & 6.7 & 4.3255 & 0.88 & & & 0.985 & -0.23434 & 0.12968 & 0.32873 \\
\hline & 10 & 3.1460 & 0.936 & & & 0.994 & -0.22599 & 0.11730 & 0.30633 \\
\hline & 20 & 1.5074 & 1.269 & & & 0.933 & -0.13041 & 0.03580 & 0.16688 \\
\hline \multirow{3}{*}{ Modified Page (II) } & 6.7 & 0.1451 & 0.88 & & & 0.985 & 0.72087 & 0.68063 & 0.75312 \\
\hline & 10 & 0.1169 & 0.936 & & & 0.994 & 0.74405 & 0.74765 & 0.77338 \\
\hline & 20 & 0.0673 & 1.269 & & & 0.933 & 0.83779 & 0.93299 & 0.8518 \\
\hline \multirow{3}{*}{ Henderson and Pabis } & 6.7 & 0.29 & & 0.996 & & 0.997 & 0.00201 & 0.00086 & 0.02690 \\
\hline & 10 & 0.35 & & 0.983 & & 0.997 & -0.00259 & 0.00054 & 0.02088 \\
\hline & 20 & 0.34 & & 0.627 & & 0.935 & 0.03908 & 0.08072 & 0.25057 \\
\hline \multirow[t]{3}{*}{ Lienear } & 6.7 & & & & -0.073 & 0.804 & -0.00041 & 0.02149 & 0.14036 \\
\hline & 10 & & & & -0.087 & 0.808 & 0.00162 & 0.02217 & 0.14126 \\
\hline & 20 & & & & -0.081 & 0.629 & 0.00189 & 0.04032 & 0.18932 \\
\hline
\end{tabular}


Table (4): Statistical parameters and the values of the coefficients specific to each model according to various microwave power densities for mint:

\begin{tabular}{|c|c|c|c|c|c|c|c|c|c|}
\hline \multirow{2}{*}{ Model } & \multirow{2}{*}{ power density } & \multicolumn{4}{|c|}{ Constants } & \multirow{2}{*}{$\mathbf{R}^{2}$} & \multirow{2}{*}{ MBE } & \multirow{2}{*}{$\mathrm{X}^{2}$} & \multirow{2}{*}{ RMSE } \\
\hline & & $\mathbf{k}$ & n & $\mathbf{a}$ & b & & & & \\
\hline \multirow{3}{*}{ Newton } & 6.7 & 0.356 & & & & 0.990 & 0.02691 & 0.00181 & 0.04021 \\
\hline & 10 & 0.493 & & & & 0.994 & 0.03982 & 0.00371 & 0.05561 \\
\hline & 20 & 0.819 & & & & 0.998 & 0.01984 & 0.00099 & 0.02730 \\
\hline \multirow{3}{*}{ Page } & 6.7 & 2.506 & 0.356 & & & 0.987 & -0.20000 & 0.09205 & 0.26758 \\
\hline & 10 & 1.603 & 1.213 & & & 0.997 & -0.17013 & 0.05692 & 0.19500 \\
\hline & 20 & 1.072 & 1.102 & & & 0.999 & -0.05066 & 0.00560 & 0.05295 \\
\hline \multirow{3}{*}{ Modified Page (I) } & 6.7 & 13.216 & 0.356 & & & 0.987 & -0.25700 & 0.09205 & 0.26758 \\
\hline & 10 & 1.4765 & 1.213 & & & 0.997 & -0.17018 & 0.05696 & 0.19488 \\
\hline & 20 & 1.0660 & 1.102 & & & 0.999 & -0.50754 & 0.05629 & 0.05305 \\
\hline \multirow{3}{*}{ Modified Page (II) } & 6.7 & 10.027 & 0.356 & & & 0.987 & -0.22237 & 0.11529 & 0.29945 \\
\hline & 10 & 6.417 & 1.213 & & & 0.997 & -0.20814 & 0.10112 & 0.25965 \\
\hline & 20 & 4.288 & 1.102 & & & 0.999 & 0.16983 & 0.09522 & 0.00226 \\
\hline \multirow{3}{*}{ Henderson and Pabis } & 6.7 & 0.35 & & 0.899 & & 0.990 & -0.00545 & 0.00256 & 0.04467 \\
\hline & 10 & 0.49 & & 0.885 & & 0.994 & 0.14112 & 0.19981 & 0.36497 \\
\hline & 20 & 0.82 & & 0.934 & & 0.998 & 0.22403 & 0.43859 & 0.46829 \\
\hline \multirow[t]{3}{*}{ Lienear } & 6.7 & & & & -0.093 & 0.789 & 0.00039 & 0.02383 & 0.14555 \\
\hline & 10 & & & & -0.138 & 0.788 & 0.00201 & 0.02887 & 0.15513 \\
\hline & 20 & & & & -0.224 & 0.800 & 0.00141 & 0.04169 & 0.17682 \\
\hline
\end{tabular}


Table (5): Statistical parameters and the values of the coefficients specific to each model according to various microwave power densities for sage:

\begin{tabular}{|c|c|c|c|c|c|c|c|c|c|}
\hline \multirow{2}{*}{ Model } & \multirow{2}{*}{ power density } & \multicolumn{4}{|c|}{ Constants } & \multirow{2}{*}{$\mathbf{R}^{2}$} & \multirow{2}{*}{ MBE } & \multirow{2}{*}{$\mathrm{X}^{2}$} & \multirow{2}{*}{ RMSE } \\
\hline & & $\mathbf{k}$ & n & $\mathbf{a}$ & b & & & & \\
\hline \multirow{3}{*}{ Newton } & 6.7 & 0.398 & & & & 0.998 & 0.01910 & 0.00078 & 0.02634 \\
\hline & 10 & 0.925 & & & & 0.995 & -0.02863 & 0.00218 & 0.04328 \\
\hline & 20 & 0.793 & & & & 0.997 & 0.02859 & 0.0000006 & 0.00067 \\
\hline \multirow{3}{*}{ Page } & 6.7 & 2.2682 & 1.062 & & & 0.998 & -0.18869 & 0.08102 & 0.25103 \\
\hline & 10 & 1.5651 & 1.151 & & & 0.996 & -0.13765 & 0.03989 & 0.16880 \\
\hline & 20 & 1.0010 & 1.167 & & & 0.998 & -0.04356 & 0.00384 & 0.04803 \\
\hline \multirow{3}{*}{ Modified Page (I) } & 6.7 & 2.1641 & 1.062 & & & 0.998 & -0.18872 & 0.08106 & 0.25109 \\
\hline & 10 & 1.4766 & 1.151 & & & 0.996 & -0.13769 & 0.03992 & 0.16886 \\
\hline & 20 & 1.0012 & 1.167 & & & 0.998 & -0.02879 & 0.00296 & 0.40193 \\
\hline \multirow{3}{*}{ Modified Page (II) } & 6.7 & 3.55 & 1.062 & & & 0.998 & -0.20085 & 0.09885 & 0.27728 \\
\hline & 10 & 2.44 & 1.151 & & & 0.996 & -0.17015 & 0.07359 & 0.22928 \\
\hline & 20 & 1.56 & 1.167 & & & 0.998 & -0.11861 & 0.04002 & 0.15497 \\
\hline \multirow{3}{*}{ Henderson and Pabis } & 6.7 & 0.40 & & 0.928 & & 0.998 & -0.00533 & 0.00091 & 0.02663 \\
\hline & 10 & 0.52 & & 0.995 & & 0.995 & 0.12528 & 0.16450 & 0.34278 \\
\hline & 20 & 0.79 & & 0.885 & & 0.997 & 0.34169 & 0.52714 & 0.56239 \\
\hline \multirow[t]{3}{*}{ Lienear } & 6.7 & & & & -0.092 & 0.778 & 0.00208 & 0.02514 & 0.14951 \\
\hline & 10 & & & & -0.117 & 0.747 & 0.00171 & 032683 & 0.16737 \\
\hline & 20 & & & & -0.170 & 0.723 & 0.03393 & 0.04200 & 0.18330 \\
\hline
\end{tabular}


Table (6): Statistical parameters and the values of the coefficients specific to each model according to various microwave power densities for basil:

\begin{tabular}{|c|c|c|c|c|c|c|c|c|c|}
\hline \multirow{2}{*}{ Model } & \multirow{2}{*}{ power density } & \multicolumn{4}{|c|}{ Constants } & \multirow{2}{*}{$\mathbf{R}^{2}$} & \multirow{2}{*}{ MBE } & \multirow{2}{*}{$\mathrm{X} 2$} & \multirow{2}{*}{ RMSE } \\
\hline & & $\mathbf{k}$ & n & $\mathbf{a}$ & b & & & & \\
\hline \multirow{3}{*}{ Newton } & 6.7 & 0.237 & & & & 0.973 & 0.09991 & 0.01665 & 0.0001 \\
\hline & 10 & 0.413 & & & & 0.998 & -0.02270 & 0.00124 & 0.00108 \\
\hline & 20 & 0.709 & & & & 0.993 & -0.01558 & 0.00143 & 0.03387 \\
\hline \multirow{3}{*}{ Page } & 6.7 & 6.0057 & 0.742 & & & 0.988 & -0.35714 & 0.24230 & 0.45573 \\
\hline & 10 & 2.7401 & 0.882 & & & 0.997 & -0.24919 & 0.14161 & 0.32589 \\
\hline & 20 & 1.2485 & 1.111 & & & 0.986 & -0.09814 & 0.02063 & 0.11126 \\
\hline \multirow{3}{*}{ Modified Page (I) } & 6.7 & 11.330 & 0.742 & & & 0.988 & -0.35715 & 0.00296 & 0.45574 \\
\hline & 10 & 3.1360 & 0.882 & & & 0.997 & -0.27695 & 0.14161 & 0.39457 \\
\hline & 20 & 1.2211 & 1.111 & & & 0.986 & -0.09814 & 0.02063 & 0.11126 \\
\hline \multirow{3}{*}{ Modified Page (II) } & 6.7 & 16.810 & 0.742 & & & 0.988 & -0.35732 & 0.24267 & 0.00249 \\
\hline & 10 & 7.606 & 0.882 & & & 0.997 & -0.25817 & 0.15795 & 0.34418 \\
\hline & 20 & 3.465 & 1.111 & & & 0.986 & -0.17262 & 0.08363 & 0.22400 \\
\hline \multirow{3}{*}{ Henderson and Pabis } & 6.7 & 0.238 & & 1.366 & & 0.973 & -0.01925 & 0.01573 & 0.11611 \\
\hline & 10 & 0.004 & & 1.073 & & 0.998 & 0.00563 & 0.00103 & 0.00072 \\
\hline & 20 & 0.700 & & 0.954 & & 0.993 & 0.00070 & 0.00181 & 0.03311 \\
\hline \multirow[t]{3}{*}{ Lienear } & 6.7 & & & & -0.071 & 0.943 & 0.00196 & 0.00654 & 0.07793 \\
\hline & 10 & & & & -0.113 & 0.860 & 0.00382 & 0.01799 & 0.12548 \\
\hline & 20 & & & & -0.173 & 0.782 & -0.00002 & 0.03664 & 0.17121 \\
\hline
\end{tabular}




\section{Effective moisture diffusivity}

The effective moisture diffusivities were estimated from the experimental drying curves. Values of $D_{\text {eff }}$ with coefficient of correlation, $r^{2}$ are given in Table 7. The variation in $\ln (\mathrm{MR})$ with drying time for each case was found to be linear. The slope became steeper with increase in microwave power level. From the slopes of these straight lines moisture diffusivities were estimated as given by Eq. of (Madamba 2003). It was observed that moisture diffusivity increased with increasing in microwave power density. The lowest values of effective moisture diffusivity were $5.03739 \times 10^{-8}, 6.01782 \times 10^{-10}, 1.72664 \times 10^{-9}, 5.769 \times 10^{-10}$ of chamomile, mint, sage, basil leaves respectively at the lowest power density.

Table (7): Moisture diffusivity and its linear equation for experimented plants according to different power density:

\begin{tabular}{|c|c|c|c|c|c|}
\hline plant & $\begin{array}{c}\text { Power, } \\
\text { W.g }{ }^{-1}\end{array}$ & Linear equation & $\mathrm{k}_{0}$ & $D_{\text {eff }}$ & $\mathrm{R}^{2}$ \\
\hline \multirow{3}{*}{ 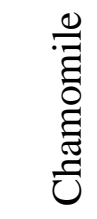 } & 6.7 & $y=-0.298 x-0.003$ & -0.298 & $5.03739 \mathrm{E}-08$ & 0.997 \\
\hline & 10 & $y=-0.353 x-0.016$ & -0.353 & $5.96711 \mathrm{E}-08$ & 0.997 \\
\hline & 20 & $y=-0.347 x-0.466$ & -0.347 & 5.86569E-08 & 0.935 \\
\hline \multirow{3}{*}{$\stackrel{\vec{J}}{\Sigma}$} & 6.7 & $y=-0.356 x-0.106$ & -0.356 & $6.01782 \mathrm{E}-10$ & 0.990 \\
\hline & 10 & $y=-0.493 x-0.121$ & -0.493 & $8.33367 \mathrm{E}-10$ & 0.994 \\
\hline & 20 & $y=-0.819 x-0.068$ & -0.819 & $1.38444 \mathrm{E}-09$ & 0.998 \\
\hline \multirow{3}{*}{ 离 } & 6.7 & $y=-0.399 x-0.073$ & -0.399 & 1.72664E-09 & 0.998 \\
\hline & 10 & $y=-0.526 x-0.104$ & -0.526 & 2.27622E-09 & 0.995 \\
\hline & 20 & $y=-0.793 x-0.121$ & -0.793 & $3.43165 \mathrm{E}-09$ & 0.997 \\
\hline \multirow{3}{*}{$\begin{array}{l}\overline{\bar{F}} \\
\tilde{\tilde{I}}\end{array}$} & 6.7 & $y=-0.237 x+0.312$ & -0.237 & $5.76900 \mathrm{E}-10$ & 0.973 \\
\hline & 10 & $y=-0.413 x+0.071$ & -0.413 & $1.00531 \mathrm{E}-09$ & 0.998 \\
\hline & 20 & $y=-0.709 x-0.047$ & -0.709 & $1.72583 \mathrm{E}-09$ & 0.993 \\
\hline
\end{tabular}

\section{CONCLUSIONS}

The drying characteristics of the experimented medicinal and aromatic plants were investigated in a microwave as a single layer using three 
levels of power density $6.7,10$ and $20 \mathrm{~W} \cdot \mathrm{g}^{-1}$. All the drying operations are seen to occur in the falling rate period.

The moisture content and drying rates were affected by the drying power density. Increasing power density caused decreasing in drying time and increasing the drying rate.

The specific energy consumption increased while drying efficiency decreased continuously as power density were increased, the minimum specific energy consumption and maximum drying efficiency were 4.96

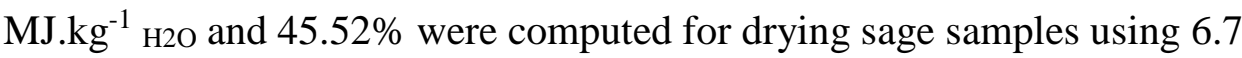
$\mathrm{W} . \mathrm{g}^{-1}$ power density. There are six thin layer drying models were fitted to the experimental moisture ratio data, the page and page I models satisfactorily described the drying behavior of basil leaves at $6.7 \mathrm{~W} . \mathrm{g}^{-1}$ and mint leaves at $10,20 \mathrm{~W} \cdot \mathrm{g}^{-1}$ with highest $\mathrm{r}^{2}$ values but for the other treatments Newton model and Henderson and Pabis model were the best. The moisture diffusivity increased with microwave power density.

\section{REFERENCES}

Agrawal, Y. C., \& R. P. Singh, (1977). Thin layer drying studies on short grain rough rice. ASAE, Paper No: 3531.

Akpinar E. K., Y. Bicer and C. Yildiz (2003). Thin layer drying of red pepper. Journal of Food Engineering, 59, 99-104.

Akpinar, E. K., A. Midilli and Y. Bicer (2003a). Single layer drying behavior of potato slices in a convective cyclone dryer and mathematical modeling. Energy Conversion and Management, 44, $1689-1705$.

Akpinar, E. K., A. Midilli and Y. Bicer (2003b). Experimental investigation of drying behaviour and conditions of pumpkin slices via a cyclone-type dryer. Journal of the Science of Food and Agriculture, 83, 1480-1489.

Amr S. and S. Dordevic ( 2000). The investigation of the quality of Sage (Salvia officinalis L.) originated from Jordan. Facta Universitatis, 1: 103-108.

AOAC. 2002. AOAC Official Method 925.10 - Solids (Total) and Moisture in Flour, Air Oven Method. In Official Methods of 
Analysis of AOAC International, 17th Ed., 2nd Rev., Ch 32, p 1. Gaithersburg, MD: The Association of Official Analytical Chemists, International.

Arslan, D., and M.M.Ozcan. 2010. Study the effect of sun, oven and microwave drying on quality of onion slices. LWT - Food Science and Technology, 43(7):1121-1127.

Chhninman, M. S. (1984). Evaluation of selected mathematical models for describing thin layer drying of in-shell pecans. Transactions of the ASAE, 27, 610-615.

Crank, J. (1975). The Mathematics of Diffusion, Clarendon Press, Oxford, U.K..

Diamante, L. M., \& Munro, P. A. (1991). Mathematical modeling of hot air drying of sweet potato slices. International Journal of Food Science and Technology, 26, 99.

Demirhan E. and B. Özebk (2010). Microwave drying characteristics of basil. Journal of Food processing and preservation. Volume 34, Issue 3 Pages 476-494.

Doymaz, I. (2004). Convective air drying characteristics of thin layer carrots. Journal of Food Engineering, 61, 359-364.

Doymaz, I. (2005). Sun drying of figs: an experimental study. Journal of Food Engineering, 71, 403-407.

Darvishi, H. (2012). Energy consumption and mathematical modeling of microwave drying of potato slices. Agric Eng Int: CIGR Journal Vol. 14, No.1.

Erenturk S., M.S.Gulaboglu and S.Gultekin (2004). The thin layer drying characteristics of rosehip. Biosys. Eng., 89(2): 159-166.

Ertekin, C., and O. Yaldiz (2004). Drying of eggplant and selection of a suitable thin layer drying model. Journal of Food Engineering, 63, 349-359.

Erle, U. (2000).Untersuchungen zur Mikrowellen-Vakuumtrocknung von Lebensmitteln, Ph.D.Thesis, Universität Karlsruhe, Aachen, Shaker Verlag. 
PROCESS ENGINEERING

Gallawa, J.C. and Microtech Productions. Copyright (C 1989-2005. http://www.gallawa.com/microtech/mwfaq.html.

Günhan, T., V.Demir, E.Hancioglu and A.Hepbasli (2005). Mathematical modelling of drying of bay leaves. Energy Conversion and Management, 46(11-12), 1667-1679.

Gölükcü, M. (2015). The Effects of drying methods, packaging atmosphere and storage time on dried pomegranate aril quality. J. of Agric. Sciences. 21: 207 - 2019.

Hayes, G.D. (1987). Food Engineering Data Handbook. England: Longman Scientific and Technical.

Hossain, M. A. and B. K. Bala (2002). Thin-layer drying characteristics for green chilli. Drying Technology, 20(2), 489-505.

Kouhila M., A. Belghit, M. Daguenet and B.C. Boutaleb (2001). Experimental determination of the sorption isotherms of mint (Mentha viridis), sage (Salvia officinalis) and verbena (Lippia citriodora). Journal of Food Engineering, 47: 281-287.

Liu, Q., \& F. W. Bakker-Arkema, (1997). Stochastic modeling of grain drying, Part 2: Model development. Journal of Agricultural Engineering Research, 66, 275-280.

Madamba, P.S. (2003). Thin layer drying models for osmotically predried young coconut. Dry. Technol. 21,1759-1780.

Maskan A, Kaya S, Maskan M (2002). Hot air and sun drying of grape leather (pestil). J. Food Eng., 54: 81-88.

Minaei, S., A. Motevali, E. Ahmadi, and M.H. Azizi, (2012). Mathematical models of drying pomegranate arils in vacuum and microwave dryers. J. Agr. Sci. Tech, 14, 311-325.

Midilli, A. and H. Kucuk (2003). Mathematical modelling of thin layer drying of pistachio by using solar energy. Energy Conversion and Management, 44, 1111-1122.

O’Callaghan, J. R., D. J. Menzies, \& P. H. Bailey, (1971). Digital simulation of agricultural dryer performance. Journal of Agricultural Engineering Research, 16, 223-244. 
Ozbek, B., and G. Dadali. 2007. Thin-layer drying characteristics and modeling of mint leaves undergoing microwave treatment. Journal of Food Engineering, 83(4): 541-549.

Soysal Y. (2004). Microwave drying characteristics of parsley. Biosystems Engineering: 89(2):167-173.

Soysal, A., S. Oztekin, and O. Eren. (2006). Microwave drying of parsley: modelling, kinetics, and energy aspects. Biosystems Engineering, 93(4): 403-413.

Simal S., A. Femenia, M. C. Garau and C. Rosella (2005). Use of exponential, Page_s and diffusional models to simulate the drying kinetics of kiwi fruit. Journal of Food Engineering, 66(3), 323-328.

Wang, Z., Sun, J., Chen, F., Liao, X. and Hu, X. (2007). Mathematical modeling on thin layer microwave drying of apple pomace with and without hot-air pre drying. J. Food Eng. 80(2), 536-544.

Westerman, P. W., G. M.White, \& I. J. Ross, (1973). Relative humidity effect on the high temperature drying of shelled corn.

Zhang, Q., \& J. B. Litchfield, (1991). An optimization of intermittent corn drying in a laboratory scale thin layer dryer. Drying Technology, 9, 383-395.

Zhang, M., J.tang, , A.S. Mujumdar and S.wang (2006). Trends in microwave-related drying of fruits and vegetables. Trends Food Sci. Tech. 17(10), 524-534.

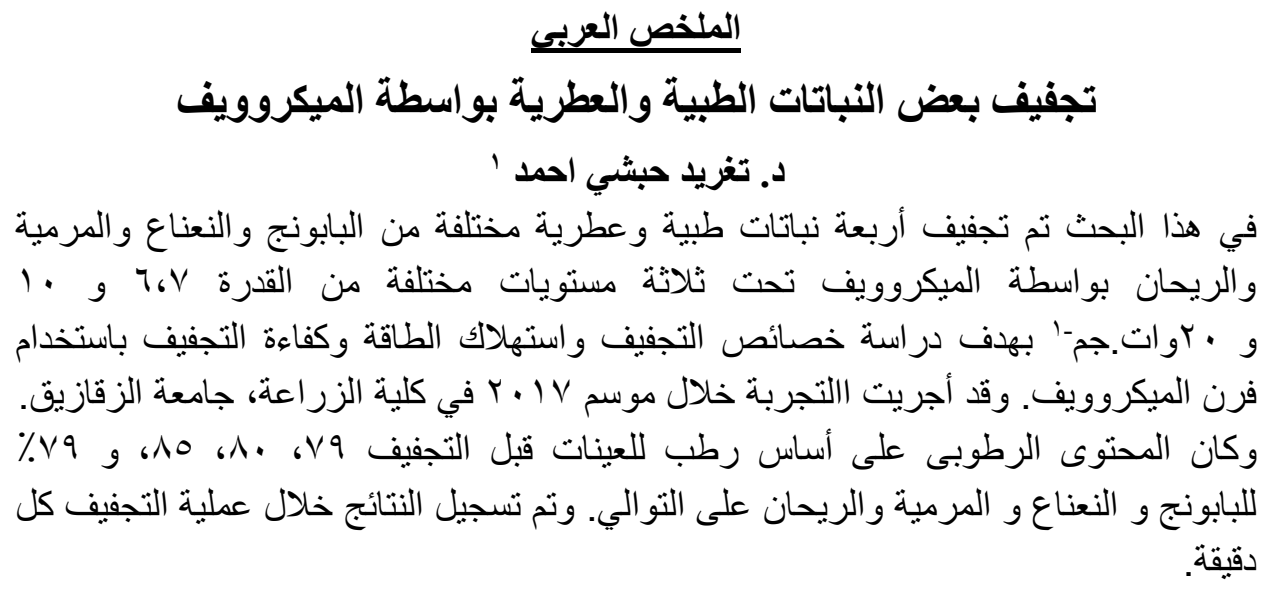

'مدرس الهندسة الزراعية - كلية الزرعة - جامعة الزقازيق. 


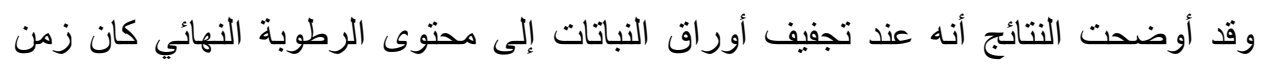

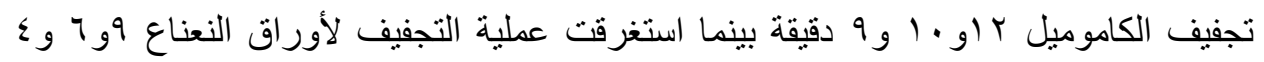

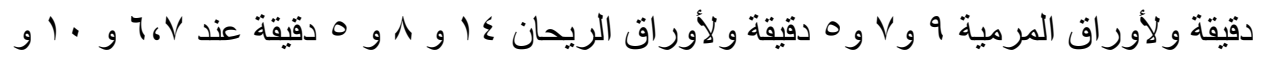
• بوات.جم-' على الترتيب.

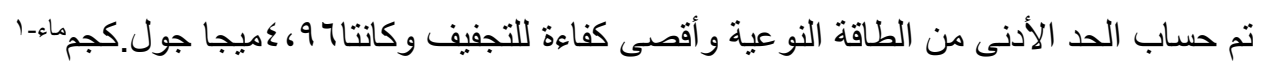

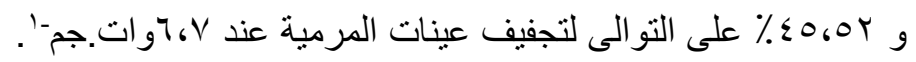

بتطبيق بعض المعادلات الرياضية أمكن وصف سلوك التجفيف بشكل مرضي باستخدام 1

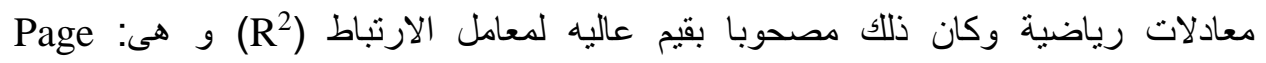
Modified Page (I)

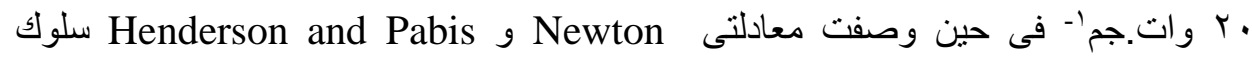
التجفيف لباقى المعاملات بشكل مرضنى وصن. وبدر اسة تأثير انتشار الرطوبة على النباتات المجفقة كانت أقل قيم لمعامل انتشار الرطوبة عند

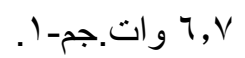

